\title{
MODEL FOR ESTIMATION OF STRESS FIELD IN THE EARTH'S CRUST
}

\section{MODEL ZA PROCENU NAPREGNUTOSTI ZEMLJINE KORE}

\author{
Torbica Slavko ${ }^{1}$, Lapčević Veljko ${ }^{1}$
}

Received: April 30, 2016

Accepted: May 25, 2016

\begin{abstract}
Stress field or in-situ stress, beside rock mass strength, determines stability or instability of underground openings. It plays key role of every rock engineering project, and has been subject of many researches. There are many theoretical models of the stress field of the Earth's crust which have more or less limited domain of applicability. However, those models usually express horizontal stresses as ratio with vertical stress component. On the other side, it is well known that deformation modulus of the rock mass is dependent on the lateral stress it is subjected to. This dependence is, herein, coupled with practical findings of the stress field behavior and incorporated into the stress filed model. As the result new formulation for the stress filed components is obtained.
\end{abstract}

Key words: field stress, rock mass, underground excavation

Apstrakt: Pored čvrstoće stenskog masiva, stabilnost podzemnih objekata zavisi od napona u stenskom masivu. Naponsko stanje stenskog masiva je jedan od glavnih faktora za procenu stabilnosti kod podzemnog otkopavanja i kao takvo je predmet mnogih istraživanja. Danas je dostupno više modela za procenu naponskog stanja, a njihova primena je manje ili više ograničena. Većina modela horizontalne komponente napona izražavaju kroz odnos sa vertikalnom komponentom napona. Sa druge strane, poznata je činjenica da modul elastičnosti stenskog masiva zavisi od intenziteta bočnih (horizontalnih) komponenti napona. Ova zavisnost je uz pračktično poznate činjenice inkorporirana u model za procenu naponskog stanja. Na ovaj način dobijena je formulacija modela za procenu komoponenti napona u stenskom masivu.

Ključne reči: naponsko stanje, stenski masiv, podzemno otkopavanje

\section{INTRODUCTION}

Stress filed of the rock mass (in the Earth's crust) is defined through the three compressional stress components. Vertical stress component $\sigma_{\mathrm{v}}$ originates from the gravity and its magnitude at some depth is expressed as the weight of the above lying rock mass. Other two stress field components are minimum horizontal stress $\sigma_{\mathrm{h}}$ and

\footnotetext{
${ }^{1}$ University of Belgrade - Faculty of Mining and Geology, Đušina 7, 11000 Belgrade, Serbia, e-mails: slavko.torbica@rgf.bg.ac.rs; veljko.lapcevic@rgf.bg.ac.rs
} 
maximum horizontal stress $\sigma_{\mathrm{H}}$. State of the field stress where those three stress components are equal is known as lithostatic stress. Biaxial stress state assumes that $\sigma_{h}=\sigma_{H}$.

The assumption of a lithostatic stress state as we penetrate deeper into the Earth's crust is known as Heim's rule. The Swiss geologist Albert Heim (1849-1937) postulated that the rock under conditions of constant, persistent loads at depth will compensate for internal differential stresses (differences in principal stresses) by creep processes, given sufficient (geological) time (Zang and Stephansson, 2009). This may be expressed as:

$$
\sigma_{h}=\sigma_{H}=\sigma_{v}=\rho \cdot g \cdot z
$$

Where:

$\rho$ - density of the above lying rocks;

$g$ - gravitational acceleration;

$z$ - depth.

Many measurements confirmed that lithostatic stress state exists below the depth of $3000 \mathrm{~m}$, while horizontal stresses may be up to 3.5 times higher than vertical at the depths to $300 \mathrm{~m}$, Teraghi and Richart (1952) came to the conclusion that in undisturbed sedimentary rock masses biaxial stress field exists:

$$
\sigma_{H}=\sigma_{h}=\frac{v}{1-v} \sigma_{v}
$$

where $v$ is the Poisson's ratio.

It is generally accepted that horizontal stress is expressed by its ratio with the vertical stress. This was proposed by many researchers as Van Heerden (1976) and Brown and Hoek (1978). Stress measurements by Rummel et al. (1986), Amadei et al. (1987), Savage et al. (1992) were focused on determination of such ratios. Useful tool for field stress estimation was created by Zang et al. (2012) in the form of the World Stress Map project that contains data about stress measurements on different locations over the world.

Well known fact is that the stress and the elastic modulus are proportional and mutually dependent. However, there is no such stress field model that incorporates elastic modulus in its formulation. Also, it is proven that elastic modulus of the rock is dependent and changes according to the lateral stress it is subjected to. Herein, those fundamental findings are incorporated into the stressfield model that tends to provide the objective engineering tool for stress estimation

\section{ELASTIC MODULUS OF ROCK AND ITS DEPENDENCE ON THE LATERAL STRESS}

Elastic modulus (Young's modulus) of rock is not constant whether the specimen is test for unconfined or triaxial compressive strength. Figure 1 illustrates the strain change for different load intervals prior to unconfined compression test. 


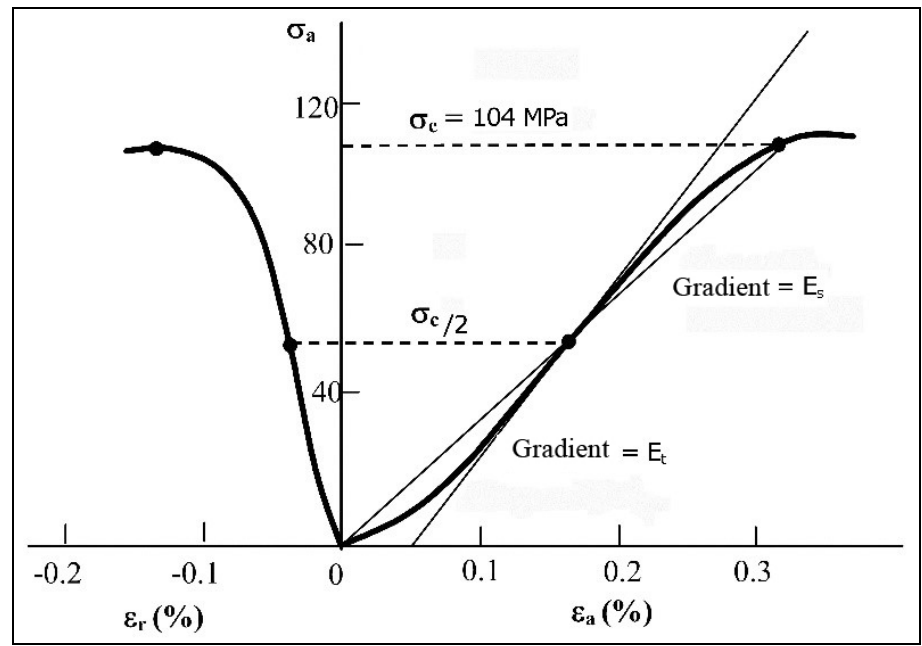

Figure 1 - Strain change for different load intervals

In triaxial compression it can be seen that elastic modulus changes with the lateral stress, and this change is smaller for higher strength rocks (Figure 2) and significant for the weaker rocks (Figure 3).

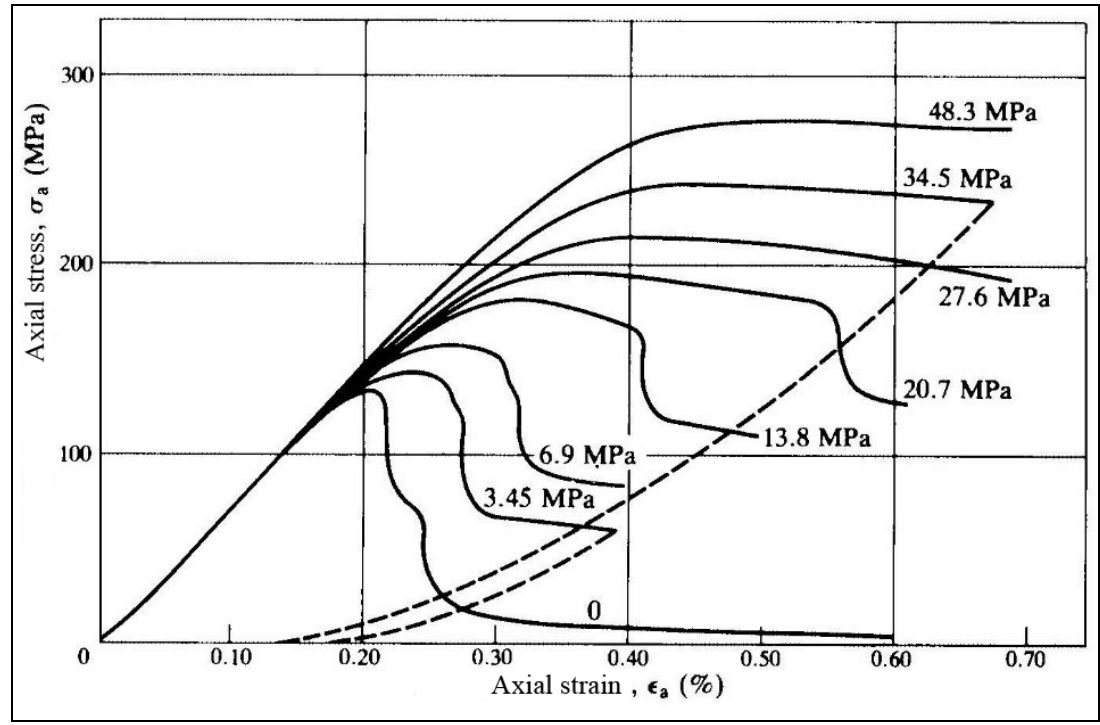

Figure 2 - Stress-strain curves for different lateral loads 


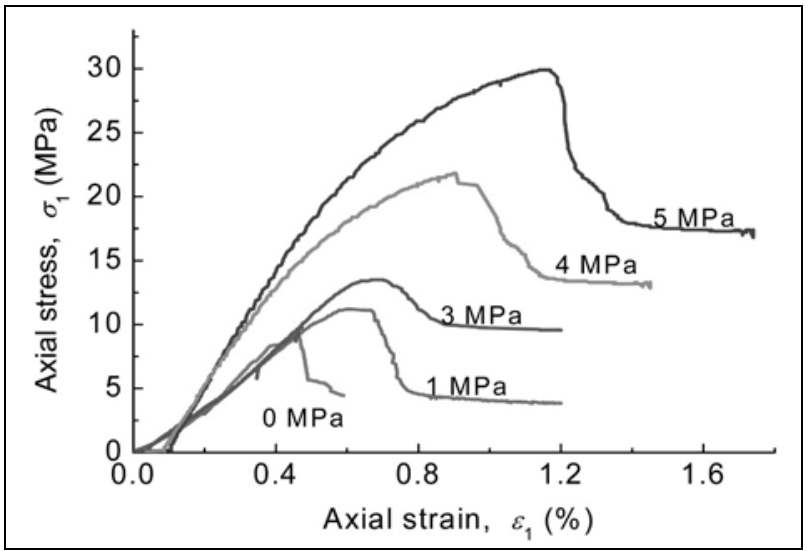

Figure 3 - Stress-strain curves for different lateral loads for the weak rock (Zhao et al. 2014)

General expression (Kulhawy, 1975) that describes the influence of the lateral stress on the elastic modulus has the form:

$$
E_{r}=E_{o} \cdot \sigma_{3}^{\alpha}
$$

Where:

$E_{r}$ - elastic modulus of rock;

$E_{o}$ - elastic modulus of rock determined by axial compression;

$\sigma_{3}$ - lateral stress;

$\alpha$ - factor that takes the value between $0-1 ; 1$ for the weak rocks and 0 for the very hard rocks.

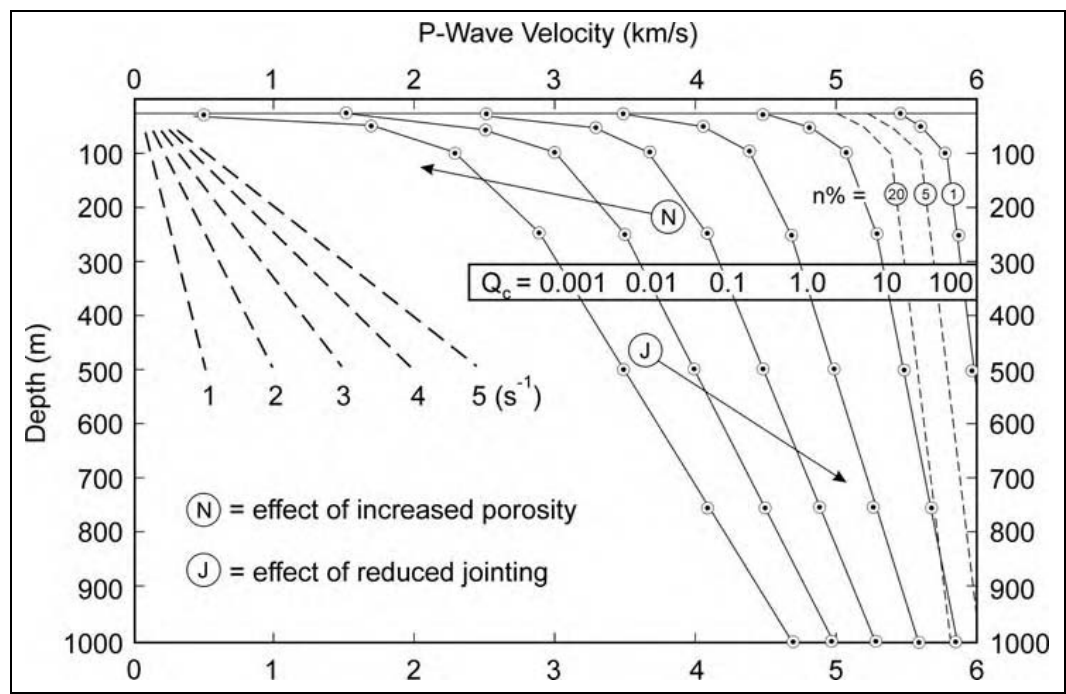

Figure 4 - Stress wave velocity change with depth (Barton, 2007) 
Back analysis (Verman et al. 1997) of several in-situ measurements confirmed the relation proposed by Kulhawy.

Barton (2007) presented the change of the stress wave velocity with the depth for the different $Q$ values. It is well known fact that stress wave velocity and elastic modulus have strong correlation. According to these findings it is obvious that elastic modulus is dependent on depth.

\section{STRESS FIELD MODEL}

Many researchers have noticed that maximum horizontal stress orientation is subparallel with the movement direction ofthe tectonic plates (Muller et al. 1992; Richardson, 1992; Zoback, 1992). From here, the conclusion is that stress field and tectonic plates movement have the same cause.

Those horizontal forces induce the highest horizontal stress at the seismogenic depth. Many measurements at different locations confirmed that maximal horizontal stress has the same magnitude as the vertical stress at the depth of $3 \mathrm{~km}$. Below this depth vertical stress magnitude is increasing faster than the magnitude of the horizontal stress.

This means that for the average growth of the vertical stress of $27 \mathrm{MPa} / \mathrm{km}$, at the depth of $3 \mathrm{~km}$ :

$$
\sigma_{v}=\sigma_{H}=80 \mathrm{MPa}
$$

At this depth stress wave velocity is $V_{p} \approx 6 \mathrm{~km} / \mathrm{s}$, assuming that Poisson's ratio value is $v=0.25$ and using average density of rocks $\rho \approx 2.7 \mathrm{~g} / \mathrm{cm}^{3}$, modulus of deformation of the rock mass can be calculated using the known expression:

$$
V_{p}=\frac{E_{m} \cdot(1-v)}{\rho \cdot(1+v) \cdot(1-2 v)}
$$

From the equation 5 and with presented values it is calculated that deformation modulus of the rock mass at the depth of $3 \mathrm{~km}$ is $E_{m} \approx 80 \mathrm{GPa}$.

With known values of the deformation modulus and the maximum horizontal stress, strain in direction of the maximum horizontal stress is calculated:

$$
\varepsilon_{H}=\frac{\sigma_{H}}{E_{m}}=\frac{80}{80000}=0.001
$$

This strain in direction of the maximum horizontal stress is same at all parts of the Earth's crust. At the location where deformation modulus is lower horizontal stress is lower and vice versa. Therefore, basic maximum horizontal stress can be expressed as:

$$
\sigma_{H}{ }^{\prime}[\mathrm{MPa}]=E_{m}[\mathrm{GPa}]
$$

Deformation modulus of rock mass can be determined using the GSI based formula (Hoek and Diederichs, 2006). This formula takes into the account the elastic modulus of the monolith rock and the jointing of the rock mass and therefore it provides very suitable estimate of rock mass deformation modulus. 


$$
E_{m}=E_{i}\left(0.02+\frac{1-\frac{D}{2}}{1+e^{\frac{60+15 D-G S I}{11}}}\right)
$$

Disturbance factor $D$ describes the blast induced damage and is applicable only to the close perimeter of the underground excavations. For the case of the rock mass outside the blast-damage zone influence $D=0$ and the equation 8 becomes:

$$
E_{m}=E_{i}\left(0.02+\frac{1-\frac{D}{2}}{1+e^{\frac{60-G S I}{11}}}\right)
$$

Elastic modulus of rock is not constant and depends on actual stress field as it was explained in section 2. Therefore it is more appropriate to use the lower (secant) elastic modulus of the monolith rock for the estimation of the deformability of the rock mass. Secant modulus $\left(E_{s}\right)$ is presented with the line that connects the begging of the stress-strain curve with the point of the peak strength. Even better estimate would be tangent elastic modulus for the known stress (depth) of $27 \mathrm{MPa} / \mathrm{km}$.

However, equation 9 doesn't include the stress field influence on the deformation modulus. Variability of the elastic modulus due to the change of the lateral stress was investigated by many researchers. General expression (Kulhawy, 1975) that describes the influence of the lateral stress on the elastic modulus is described by Equation 3. For the estimate of the deformation modulus of the rock mass in direction of the maximum horizontal stress, lateral stress $\sigma_{3}$ is equal to the vertical stress component in magnitude of $\approx 27 \mathrm{MPa} / \mathrm{km}$. Therefore, Equation 3 is used to express modulus of deformation of the rock mass in direction of the maximum horizontal stress, in the function of the lateral stress, is:

$$
E_{m}^{H}=E_{m} \cdot(27 \cdot H)^{\alpha}
$$

Factor $\alpha$ that takes its value between $0-1$ is best to describe using the GSI value as:

$$
\alpha=1-\frac{G S I}{100}
$$

After the substitution, equation 10 has the form:

$$
E_{m}^{H}=E_{m} \cdot(27 \cdot H)^{\left(1-\frac{G S I}{100}\right)}
$$

Equation 7, used to determine the basic maximum horizontal stress component, becomes:

Where:

$$
\sigma_{H}^{\prime}=E_{m} \cdot(27 \cdot H)^{\left(1-\frac{G S I}{100}\right)}
$$

$\sigma_{H}{ }^{\prime}$ - basic maximum horizontal stress [MPa];

$E_{m}$ - modulus of deformation of the rock mass [GPa];

$H$ - depth $[\mathrm{km}]$;

GSI - Geological Strength Index. 
Basic vertical (gravitational) stress component is:

$$
\sigma_{v}^{\prime}=27 \cdot H
$$

If $\sigma_{v}^{\prime}=\sigma_{H}{ }^{\prime}$ then:

$$
\begin{aligned}
& \sigma_{v}=\sigma_{v}{ }^{\prime}=27 \cdot H \\
& \sigma_{H}=\sigma_{H}{ }^{\prime}+\left(\sigma_{v}{ }^{\prime}-\sigma_{H}{ }^{\prime}\right) \frac{v}{1-v}
\end{aligned}
$$

If $\sigma_{v}^{\prime}<\sigma_{H}{ }^{\prime}$ then:

$$
\begin{aligned}
& \sigma_{v}=\sigma_{v}{ }^{\prime}+\left(\sigma_{H}{ }^{\prime}-\sigma_{v}{ }^{\prime}\right) \frac{v}{1-v} \\
& \sigma_{H}=\sigma_{H}{ }^{\prime}=E_{m} \cdot(27 \cdot H)^{\left(1-\frac{G S I}{100}\right)}
\end{aligned}
$$

Minimum horizontal stress is expressed as:

$$
\sigma_{h}=\left(\sigma_{H}+\sigma_{v}\right) \frac{v}{1-v}
$$

\section{CONCLUSION}

Model presented herein is based on the facts that tectonic plate's movement and maximum horizontal stress direction have same orientation and their origin is probably the same. Also, having in mind that measurements have confirmed that at the depths around $3000 \mathrm{~m}$ lithostatic stress state is present, horizontal stress magnitude can be estimated as the starting point of this model. Strain in the direction of the maximum horizontal stress is used to express relation between maximum horizontal stress and deformation modulus of the rock mass at the depth of $3000 \mathrm{~m}$. It is well known that deformation modulus of rock mass depends on the elastic modulus of the monolith rock and the jointing of the rock mass. Deformation modulus of the rock mass can be also expressed in terms of the GSI value, which is practical for common rock engineering.

Another fact used here is that elastic modulus of rock depends on the lateral stress and modulus values defined for different lateral stress magnitudes differ significantly. This implies that deformation modulus of the rock mass will change with depth.

Combination of these fundamental findings provided the new model of the stress field that incorporates deformation modulus of the rock mass and the GSI classification. In this manner practical tool for the stress estimation is provided suitable for common rock engineering problems.

Model expresses basic vertical and maximum horizontal stress components for cases when basic vertical stress component is larger than basic maximum horizontal stress component and vice versa. Basic maximum horizontal stress component incorporates only stress dependence on deformation modulus, depth and GSI value, while maximum horizontal stress in total incorporates both basic and lithostatic stress. Same is provided for vertical and minimum horizontal stress components. 
In this manner objective model based on the fundamental mechanical facts and GSI classification is provided. Model considers horizontal stress independently for the vertical stress unlike the existing models that express the horizontal stress as the fraction of the vertical, gravitational stress.

\section{REFERENCES}

[1] AMADEI, B., SAVAGE, W. and SWOLFS, H. (1987) Gravitational stresses in anisotropic rock masses. International Journal of Rock Mechanics and Mining Sciences \& Geomechanics Abstracts, 24, pp. 5-14.

[2] BARTON, N. (2007) Rock quality, seismic velocity, attenuation and anisotropy. Boca Raton (FL): CRC press.

[3] BROWN, E. and HOEK, E. (1978) Trends in relationships between measured in-situ stresses and depth. International Journal of Rock Mechanics and Mining Sciences \& Geomechanics Abstracts, 15 (4), pp. 211-215.

[4] HOEK, E., and DIEDERICHS, M.S. (2006) Empirical estimation of rock mass modulus. International Journal of Rock Mechanics and Mining Sciences, 43 (2), pp. 203-215.

[5] KULHAWY, F.H. (1975) Stress deformation properties of rock and rock discontinuities. Engineering Geology, 9 (4), pp. 327-350.

[6] MULLER, B. et al. (1992) Regional patterns of tectonic stress in Europe. Journal of Geophysical Research: Solid Earth, 97 (B8), pp. 11783-11803.

[7] RICHARDSON, R.M. (1992) Ridge forces, absolute plate motions, and the intraplate stress field. Journal of Geophysical Research: Solid Earth, 97 (B8), pp. 11739-11748.

[8] RUMMEL, F., MÖHRING-ERDMANN, G. and BAUMGÄRTNER, J. (1986) Stress constraints and hydrofracturing stress data for the continental crust. Pure and Applied Geophysics, 124 (4), pp. 875-895.

[9] SAVAGE, W., SWOLFS, H. and AMADEI, B. (1992) On the state of stress in the near-surface of the Earth's crust. Pure and Applied Geophysics, 138 (2), pp. 207-228.

[10] TERAGHI, K. and RICHART, F.E. (1952) Stresses in Rock About Cavities. Géotechnique, 3 (2), pp. 57-90.

[11] VAN HEERDEN, W.L. (1976) Practical application of the CSIR triaxial strain cell for rock stress measurements. In: Proceedings of the I.S.R.M. Symposium, Investigation of Stress in Rock: Advances in Stress Measurement; Preprints of Papers. Sydney, 1976. Barton, ACT: Institution of Engineers, pp. 1-6.

[12] VERMAN, M. et.al. (1997) Effect of tunnel depth on modulus of deformation of rock mass. Rock mechanics and rock engineering, 30 (3), pp. 121-127.

[13] ZANG, A. and STEPHANSSON, O. (2009) Stress Field of the Earth's Crust. Netherlands: Springer.

[14] ZANG, A. et al. (2012) World stress map database as a resource for rock mechanics and rock engineering. Geotechnical and Geological Engineering, 30 (3), pp. 625-646. 
[15] ZHAO, Z., WANG, W. and Gao, X. (2014) Evolution laws of strength parameters of soft rock at the post-peak considering stiffness degradation. Journal of Zhejiang University-SCIENCE A (Applied Physics \& Engineering), 15 (4), pp. 282-290

[16] ZOBACK, M.L. (1992) First-and second-order patterns of stress in the lithosphere: The world stress map project. Journal of Geophysical Research: Solid Earth, 97 (B8), pp. 11703-11728. 